\section{International Scientific Journal Theoretical \& Applied Science}

p-ISSN: 2308-4944 (print)

e-ISSN: 2409-0085 (online)

Year: 2015

Issue: 08

Volume: 28

Published: $30.08 .2015 \quad$ http://T-Science.org

SECTION 7. Mechanics and machine construction.
Nikolai Vladimirovich Semenchenko

Student of the Department «Equipment and technology of machine-building production»" FSBEI HPE «Togliatti State University», Russia bonder64@mail.ru

Konstantin Olegovich Hryachkov Student of the Department «Equipment and technology of machine-building production»» FSBEI HPE «Togliatti State University», Russia

\title{
CONTROL METHOD OF DEFORMATION CLADDING BASED ON POWER PARAMETERS
}

Abstract: This report describes the method of process control deformation cladding based on power parameters. We created the nomogram for determining the maximum strength in the contact zone during deformation cladding of flat surfaces. We have developed agloritm of an automatic control system, which eliminate the influence of wear wire and stabilize the quality parameters of coating layer at high level.

Key words: wire tool; cladding; contact force; nomogram, control method.

Language: English

Citation: Semenchenko NV, Hryachkov KO (2015) CONTROL METHOD OF DEFORMATION CLADDING BASED ON POWER PARAMETERS. ISJ Theoretical \& Applied Science 08 (28): 89-91.

Soi: http://s-o-i.org/1.1/TAS-08-28-15 Doi: crossef http://dx.doi.org/10.15863/TAS.2015.08.28.15

At present, methods of combined manufacturing of the surface layer apply to improve durability and reliability of details. One of these methods is deformation cladding by flexible tool [15]. This manufacturing method improves quality of surface layer. It is increases fatigue endurance, contact endurance, corrosion resistance and wear resistance.

The force $(P)$ in the contact zone of compressed-bent wire with surface of detail is one of the most important energy and power characteristics. It has strong effect on the quality of coatings produced. Changing the contact force worsens the surface layer during processing. A good solution of this problem is control process of deformation cladding. This makes high quality of the coating formed. Contact force changes throughout contact zone. Figure 1 shows the dependence of the contact force for one of the wire of metal brush.

Process parameters: the diameter of wire $d=0,22 \mathrm{~mm}$; the radius of fictitious seal $R=100 \mathrm{~mm}$; the length of wire curved $-l_{H}=60 \mathrm{~mm}$, negative allowance $-N_{H}=1,5 \mathrm{~mm}$.

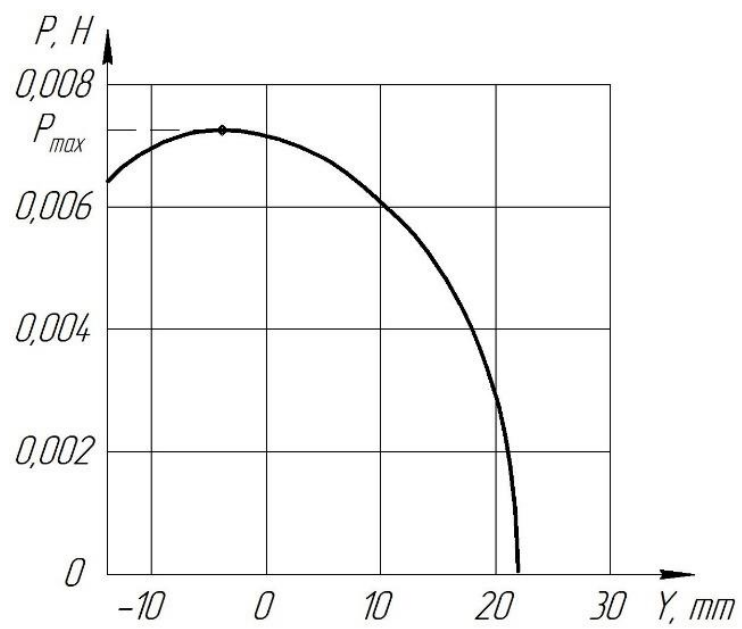

Figure 1 - Dependence of contact force with Y coordinate throughout the contact zone [6]. 


\begin{tabular}{|c|c|c|c|c|c|}
\hline Impact Factor: & $\begin{array}{l}\text { ISRA (India) } \\
\text { ISI (Dubai, UAE } \\
\text { GIF (Australia) } \\
\text { JIF }\end{array}$ & $\begin{array}{l}=1.344 \\
=0.829 \\
=0.356 \\
=1.500\end{array}$ & $\begin{array}{l}\text { SIS (USA) } \\
\text { PИНЦ (Russia } \\
\text { ESJI (KZ) } \\
\text { SJIF (Morocco }\end{array}$ & $\begin{array}{l}=0.912 \\
=0.179 \\
=1.042 \\
=\mathbf{2 . 0 3 1}\end{array}$ & ICV (Poland) \\
\hline
\end{tabular}

We determine the value of the function extremum $\left(P_{\max }\right)$ based on the schedule (Fig. 1) and take it for a control parameter. The maximum contact force influences formation of coating thickness. Large the contact force causes shearing of the coating layer with help flexible elements of brush. This is unwanted return process of cladding material from the details. Natural wear of the wire affects parameters of deformation cladding, this leads to change of the contact force.

Natural wear of wire defines according article [7, 8], $\mathrm{mm}$ :

$$
\Delta \ell=\mu \cdot \tau^{u з н}
$$

where $\mu$ - equivalent speed of natural wear, $\tau^{u 3 н}-$ time of natural wear $\left(\tau^{u 3 H}=250 \ldots 280\right.$ hour $)$ [9].

After determining the natural wear, we can calculate change of the negative allowance $\Delta N$. This will make the condition $P_{\max }=$ const. Control of process based on this principle of calculation.

Nomogram for definition maximum stress and character wear of the wire tool was proposed in the article [10].

We created the nomogram for determining the maximum contact force without the rotation dynamics (Figure 2). This nomogram illustrates this control method.

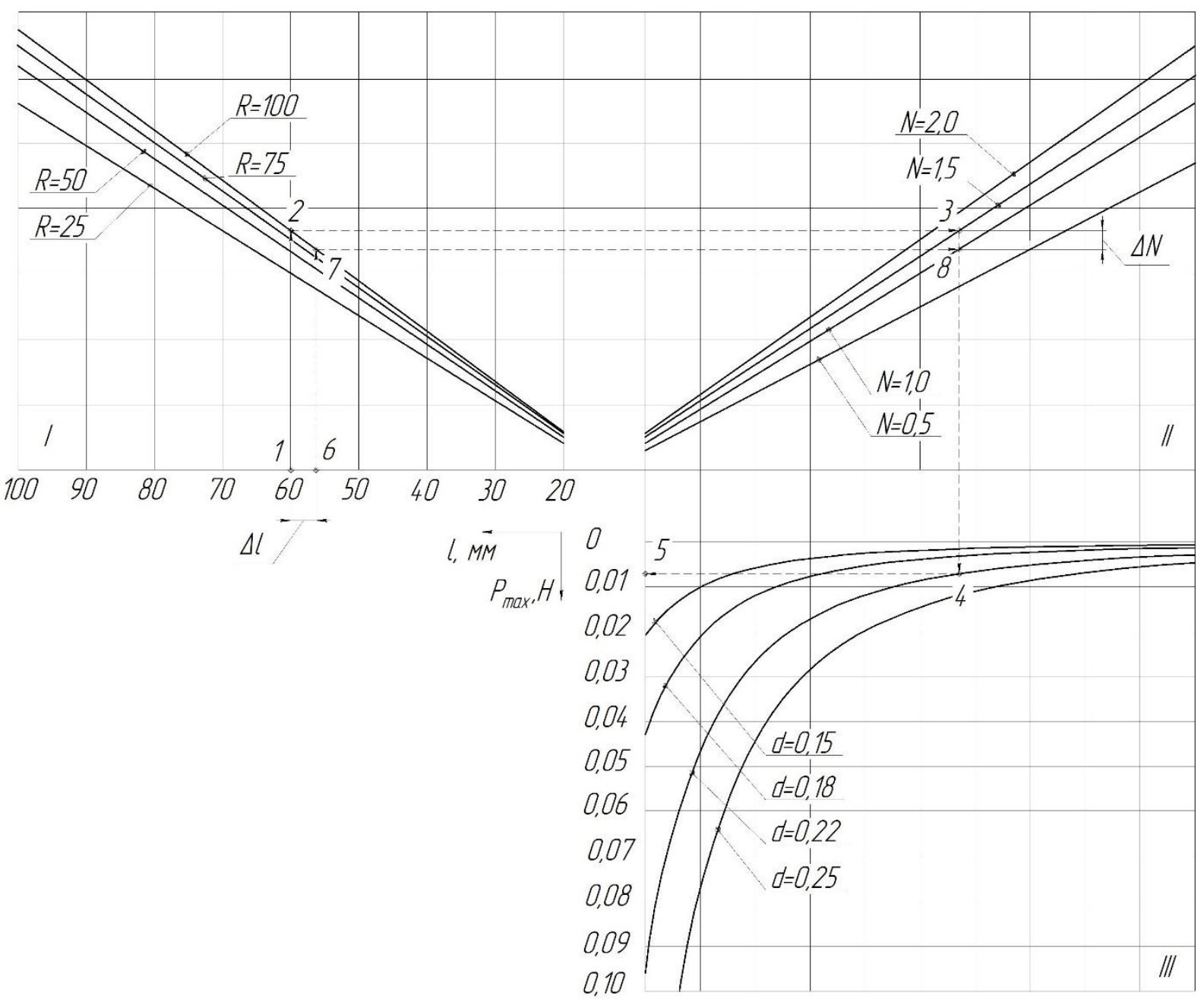

Figure 2 - The nomogram for determining the maximum strength in the contact zone during deformation cladding of flat surfaces.

This nomogram enough shows the principle of process control. In the example we use the previously defined parameters. Packing density of the wire provides a constant radius fictitious seal ( $R=$ const $)$. We calculate necessary change of negative allowance to contact force is being constant, with normal wear of wire tool.
We determine route of the nomogram (Fig. 2) 1-2-3-4-5. We choose the processing parameters in respective quadrants and get the maximum contact force $-P_{\max }$. We define the define length of the wire at the currently time of processing $-l_{\kappa}$.

$$
\ell_{\kappa}=\ell_{H}-\Delta \ell
$$


The control system makes adjustments negative allowance $(\Delta N)$ in process of cladding to maintain a constant contact force. Adjustments negative allowance is the difference between points 3 and 8 at the nomogram (Fig. 2). The new route $6-7-8-4-5$ is fully matching these criteria $P_{\max }=$ const.
If you will use this nomogram you easy pick up the appropriate mode based on the power parameters of process in the cladding zone. If you will use this control method you can eliminate the influence of wear wire and stabilize the quality parameters of coating layer at high level.

Scientific research was executed under direction of Guljaev V.A, Cand. of Sc., associate professor, and Zotov A.V., senior lecturer of the Department «Equipment and technology of machine-building production» FSBEI HPE «Togliatti State University», Russia.

\section{References:}

1. Platov SI, Dema RR, Zotov AV (2013) Model' formirovaniya tolshchiny plakirovannogo sloya na detalyah par treniya tekhnologicheskogo oborudovaniya // Vestnik MGTU im. G.I. Nosova. 2013. №1. pp. 69-72.

2. Ancupov VP (1999) Teoriya i praktika plakirovaniya izdelij gibkim instrumentom. Magnitogorsk: MGTU im. G.I. Nosova, 1999. $241 \mathrm{p}$.

3. Belevskij LS (1987) Poverhnostnoe plasticheskoe deformirovanie $\mathrm{s}$ odnovremennym naneseniem pokrytij // Izv. Vuzov. Chernaja metallurgija. - 1987. - №7. pp. 104-106.

4. Kurguzov YI (2010) Uprochnenie kromok lopatok rabochih koles gazoturbinnyh dvigatelej // Vestnik Samarskogo gosudarstvennogo tekhnicheskogo universiteta. Seriya: tekhnicheskie nauki. 2010. № 4. pp. 120-127.

5. Belevskij LS (1996) Plasticheskoe deformirovanie poverhnostnogo sloya i formirovanie pokrytiya pri nanesenii gibkim instrumentom. - Magnitogorsk: Licej RAN, 1996. - $231 \mathrm{p}$.

6. Zotov AV (2012) Metodika rascheta geometricheskih i silovyh parametrov zony kontakta pri plakirovanii izdelij gibkim instrumentom // Vektor nauki Tol'yattinskogo gosudarstvennogo universiteta. 2012. № 3. pp. 85-88.

7. Bokov AI (2001) Povyshenie dolgovechnosti detalej metallurgicheskogo oborudovaniya metodom plakirovaniya gibkim instrumentom $\mathrm{s}$ uchetom ego iznosa i ustalostnogo razrusheniya: dissertaciya kandidata tekhnicheskih nauk. Magnitogorsk 2001. 129 p.

8. Semenchenko NV, Zotov AV, Emel'yanova NA (2014) Vliyanie iznosa instrumenta na moshchnost' i udarnuyu silu pri upravlenii processom plakirovaniya // Sbornik nauchnyh dokladov «Sovremennaya nauka. Novye perspektivy» (30.01.2014 - 31.01.2014) Varshava: Bydgoshch: Sp. z o.o. «Diamond trading tour», 2014. pp. 20-23.

9. Savel'ev VB, Ancupov VP, Bokov AI (1999) Nomogramma dlya opredeleniya resursa gibkogo plakiruyushchego instrumenta // Modelirovanie i razvitie tekhnologicheskih processov obrabotki metallov davleniem: sb. nauch. tr. Magnitogorsk: MGTU im. G.I. Nosova. 1999. pp. 183-189.

10. Zotov AV, Semenchenko NV (2013) Selecting a material for pile wire tool // Pressing issues and priorities in development of the scientific and technological complex: research articles, B\&M Publishing, San Francisco, California. 2013. pp. 113-116. 